\title{
PENJABARAN PRINSIP DEMOKRASI DALAM PEMBENTUKAN KEBIJAKAN DAERAH
}

\author{
Anak Agung Istri Ari Atu Dewi, \\ Luh Nila Winarni \\ Fakultas Hukum Universitas Udayana \\ ari_atudewi@unud.ac.id; \\ luhnilawinarni@gmail.com
}

\begin{abstract}
The principles of democracy adopted by transparency and openness in the formation of regional policies. Legally formal democratic principles are regulated in Law 12 of 2011 concerning the Establishment of Legislation. In this context, it is necessary to study and understand about the formation of regional policies based on democratic principles and the meaning of democracy. The research method used is a normative research with statue approach and philosophical approach. The results of discussion are 1) the meaning of the elaboration of the democracy principles in the formation of regional policies is understood as involve the community in the formation of regional policies. Community involvement is called community participation which must be involved in every stage of regional policy formation. 2) The descriptions of principle of democracy to described in every process when forming regional policies, starting from the planning, drafting, discussion, determination and promulgation of regional legal policies. The democracy principles must be described in substance of regional legal policies.
\end{abstract}

Key words : Democracy, Formation of Regional Policies

\begin{abstract}
Abstrak
Prinsip demokrasi yang dianut oleh Indonesia menuntut adanya transparansi dan keterbukaan dalam pembentukan kebijakan daerah. Secara legal formal prinsip demokrasi diatur dalam UU 12 Tahun 2011 Tentang Pembentukan Peraturan Perundang-Undangan. Dalam konteks ini, perlu dikaji dan dipahami apakah dalam pembentukan kebijakan daerah sudah berasaskan prinsip demokrasi serta perlu dikaji makna demokrasi dalam pembentukan kebijakan daerah. Metode penelitian yang digunakan adalah metode penelitian normatif dengan pendekatan peraturan perundangundangan dan pendekatan filsafat. Hasil pembahasan adalah 1) bahwa makna dari penjabaran prinsip demokrasi dalam pembentukan kebijakan daerah dipahami pelibatan masyarakat dalam pembentukan kebijakan daerah. Pelibatan masyarakat dalam konteks legal formal disebut partisipasi masyarakat yang wajib terlibat dalam setiap tahapan pembentukan kebijakan daerah. 2) Penjabaran prinsip demokrasi yang dimaknai sebagai partisipasi masyarakat dalam pembentukan kebijakan daerah dilakukan pada setiap proses pembentukan kebijakan daerah. Mulai dari tahap perencanaan, penyusunan, pembahasan, penetapan dan pengundangan kebijakan hukum daerah serta penjabaran prinsip demokrasi juga dituangkan dalam subtansi kebijakan hukum daerah.
\end{abstract}

Kata Kunci : Demokrasi, Pembentukan Kebijakan Daerah.

Anak Agung Istri Ari Atu Dewi; Luh Nila Winarni, Penjabaran Prinsip Demokrasi Dalam Pembentukan Kebijakan Daerah 


\section{PENDAHULUAN}

\section{Latar belakang masalah}

Indonesia merupakan Negara hukum yang demokratis yang bersumberkandari konsep kedaulatan hukum dan kedaulatan rakyat. Prinsip kedaulatan dimaksud ditegaskan dalam Pasal 1 ayat (2) UUD NRI 1945. Selanjutnya prinsip Negara hukum juga diatur dalam Pasal 1 ayat (3) UUD NRI 1945 yang secara tegas menyatakan "bahwa Negara Indonesia adalah Negara hukum. Prinsip-prinsip pokok tersebut secara tegas menyatakan bahwa suatu negara dibangun berdasarkan hukum dan demokrasi. Menurut Padmo Wahjono ${ }^{1}$ menegaskan bahwa Negara hukum yang demokratis merupakan pola bernegara yang diidealkan. Hal ini mempunyai makna bahwa hukum yang berlaku dalam suatu negara haruslah dirumuskan secara demokratis yaitu suatu hukum yang dikehendaki oleh rakyat. Prinsip ini membawa konsekuensi bahwa sebagai Negara hukum, segala tindakan penyelenggara Negara dan warga Negara harus sesuai dengan aturan hukum yang berlaku. Hukum yag berlaku adalah hukum yang sesuai dengan kebutuhan masyarakat. Oleh karena itu dituntut adanya perencanaan dalam membentuk aturan hukum termasuk didalamnya menentukan tujuan yang hendak dicapai dan cara-cara untuk mencapai tujuan tesebut. Sehingga dapat dikatakan bahwa hokum bersifat instrumental yaitu instrument untuk mencapai tujuan. Apabila dipahami maka hal di atas sesuai dengan hakikat kebijakan public, dimana kebijakan publik itu selalu mempunyai tujuan tertentu atau merupakan tindakan yang berorientasi pada tujuan. Sebagaimana disebutkan oleh Thomas R Dye bahwa kebijakan public adalah apapun yang dipilih oleh pemerintah untuk dilakukan atau tidak dilakukan (is whatever government choose to do or not to do) ${ }^{2}$. Pernyataan ini dapat diartikan bahwa bila pemerintah memilih untuk melakukan sesuatu maka harus ada tujuannya (obyektif) dan kebijakan public itu meliputi semua tindakan pemerintah, jadi bukan semata-mata merupakan pernyataan keinginan pemerintah atau pejabat pemerintah. Selanjutnya Seidman menyatakan bahwa hukum merupakan pernyataan kebijakan publik, hal ini dapat dipahami bahwa apabila pemerintah mengajukan kebijakan public atau berupaya melaksanakanya, maka pejabat-pejabat pemerintah (para penyusun kebijakan)

1 Janedjri M. Gaffar, 2013, Demokrasi dan Pemilu Di Indonesia, Jakarta, Konstitusi Press khasanah peradaban hukum \& konstitusi, Jakarta, hlm. .75.

${ }^{2}$ M Irfan Islamy, 1997, Prinsip-Prinsip Perumusan Kebijaksanaan Negara, Jakarta, Bumi Aksara, hlm.18.

Anak Agung Istri Ari Atu Dewi; Luh Nila Winarni, Penjabaran Prinsip Demokrasi Dalam Pembentukan Kebijakan Daerah 
harus menerjemahkan kebijakan menjadi peraturan-peraturan yang harus dilaksanakan oleh pejabat-pejabat lainnya ${ }^{3}$.

Pernyataan kebijakan publik di daerah berupa Produk hukum daerah yang merupakan produk hukum yang berbentuk peraturan yang meliputi Perda, Perkada, Peraturan Bersama Kepala Daerah, Peraturan DPRD dan berbentuk Keputusan yang meliputi Keputusan Kepala Daerah, Keputusan DPRD, Keputusan Pimpinanan DPRD dan Keputusan Badan Kehormatan DPRD. Perda merupakan salah satu bentuk kebijakan daerah yang berbentuk regulative Perda yang dibentuk harus dilaksanakan oleh pejabat-pejabat daerah. Dalam hal ini tugas pemerintah daerah (eksekutif) adalah melaksanakan kebijakan daerah sebagaimana mestinya sesuai dengan pembangunan daerah. Hal ini seturut dengan apa yang dinyatakan oleh I Wayan Parsa ${ }^{4}$ yang menyatakan bahwa salah satu asas yang menjadi dasar penyelengaraan pemerintah daerah adalah asas desentralisasi. Melalui desentralisasi maka pemerintah (pusat) menyerahkan wewenang pemerintahan kepada daerah otonom untuk mengatur dan mengurus urusan pemerintahan dalam sisten Negara Kesatuan Republik Indonesia. Dengan adanya penyerahan itu berarti kewenangan untuk menyelengarakan urusan tertentu telah beralih dari pemerintah pusat kepada pemerintah daerah otonom yang selanjutnya diwujudkan dalam bentuk Perda.

Dalam konteks pembentukan, Perda tunduk dan patuh pada kaidahkaidah hokum sebagaimana dimaksud dalam UU No. 12 Tahun 2011 tentang Undang-Undang Pembentukan Peraturan Perundang-undangan (selanjutnya disebut UU P3). Selanjutnya pembentukan Peraturan Daerah juga sebagai wujud pelaksanaan otonomi daerah dan tugas pembantuan, Sebagaiamana di tegaskan dalam Pasal 236 UU Nomor 23 Tahun 2014 tentang Pemerintah Daerah menyatakan bahwa:

(1) Untuk menyelenggarakan Otonomi Daerah dan Tugas Pembantuan, Daerah membentuk Perda.

(2) Perda sebagaimana dimaksud pada ayat (1) dibentuk oleh DPRD dengan persetujuan bersama kepala Daerah.

(3) Perda sebagaimana dimaksud pada ayat (1) memuat materi muatan:

a. penyelenggaraan Otonomi Daerah dan Tugas Pembantuan; dan

3 Ann Seidman, Robert B Seidman dan Nelis Abeyeskere, Penyususnan Rancangan Undang-Undang Dalam Perubahan Masyarakat Yang Demokratis, Sebuah Panduan Untuk Pembuat Rancangan Undang-Undang, yang diterjemahkan oleh Dr. Johanes Usfunan, Endah P Wardhani, Ningrum Sirait, Business Advisory Indonesia, University of San Francisco School of Law Indonesia Program, ELIPS II, 2002, hlm. 4.

4I Wayan Parsa, "Sanksi Paksaan Pemerintah (Bertuursdwang) Dalam Rangka Penegakan Peraturan Daerah", Pidato Pengukuhan Jabatan Guru BEsar Tetap Bidang Ilmu Hukum/Hukum administrasi Negara pada Fakultas Hukum Universitas Udayana, Sabtu, 21 November 2009, hlm.3.

Anak Agung Istri Ari Atu Dewi; Luh Nila Winarni, Penjabaran Prinsip Demokrasi Dalam Pembentukan Kebijakan Daerah 
b. penjabaran lebih lanjut ketentuan peraturan perundang-undangan yang lebih tinggi.

(4) Selain materi muatan sebagaimana dimaksud pada ayat (3) Perda dapat memuat materi muatan lokal sesuai dengan ketentuan peraturan perundang-undangan.

Dalam konteks ini Kabupaten Badung memiliki kewenangan dalam pembentukan Perda sesuai dengan kebutuhannya. Terkait dengan dasar kewenangan yang lain Kabupaten Badung dalam pembentukan perda maka dalam Undang-Undang Nomor 12 Tahun 2011 tentang Pembentukan Peraturan Perundang-undangan juga jelas mengatur mengenai konsep perda. Konsep Perda diatur dalam Pasal 1 angka 8 yang menyatakan Peraturan Daerah Kabupaten/Kota adalah Peraturan Perundang-undangan yang dibentuk oleh Dewan Perwakilan Rakyat Daerah Kabupaten/Kota dengan persetujuan bersama Bupati/Walikota. Paparan di atas menunjukan bahwa ada kewenangan Pemerintah Daerah Kabupaten/Kota untuk membentuk Peraturan Daerah sebagai bentuk produk hukum di daerah.

Dalam Pasal 14 Undang-Undang Nomor 12 Tahun 2011 dengan tegas mengatur materi muatan yang terkandung dalam Perda yaitu bahwa materi muatan Peraturan Daerah Provinsi dan Peraturan Daerah Kabupaten/Kota berisi materi muatan dalam rangka penyelenggaraan otonomi daerah dan tugas pembantuan serta menampung kondisi khusus daerah dan/atau penjabaran lebih lanjut Peraturan Perundang-undangan yang lebih tinggi. Pemahaman Penormaan dalam Pasal 14 ini menunjukan bahwa Kabupaten Badung di beri kebebasan untuk membentuk Perda yang materi muatannya sesuai dengan kondisi khusus daerahnya .

Disisi lain, Pelaksanaan pembentukan peraturan daerah (legislasi daerah) biasanya didekati secara dikotomi yaitu pengkajian dari perspektif yuridis-normatif dan perspektif lain dari socio-politik. Dalam Perspektif socio politik oleh Mahfud MD menegaskan bahwa proses pembentukan hukum positif (in abstracto) akan selalu dipengaruhi konfigurasi politik tertentu yang berinteraksi dalam proses tersebut. Secara konseptual yang berlaku dan dianut oleh Negara dapat ditelaah secara dikotomis yaitu konfigurasi poltik demokratis dan otoriter ${ }^{5}$. Pengkajian yuridis-normatif dan socio-politik dalam proses pembentukan peraturan daerah merupakan konsep prosedural (masuk dalam aspek normatif demokrasi).

Oleh karena itu yang menjadi focus perhatian penulis dalam kajian ini adalah untuk dikaji lebih lanjut pembentukan peraturan daerah secara procedural (yuridis normative) yaitu menelaah makna prinsip demokrasi dalam

${ }^{5}$ Moh. Mahfud MD,2009, Politik Hukum Di Indonesia, Jakarta: Rajawali Pers, hlm. 20.

Anak Agung Istri Ari Atu Dewi; Luh Nila Winarni, Penjabaran Prinsip Demokrasi Dalam Pembentukan Kebijakan Daerah 
pembentukan kebijakan daerah Kabupaten Badung dan apakah dalam penormaan pasal dalam kebijakan daerah dimaksud sudah menjabarkan prinsip demokrasi. Dua persoalan ini dipandang relevan untuk di kaji dan di bahas untuk menemukan jawaban atas kebenaran ilmiah terkait dengan pokok persoalan yang diajukan yaitu mencari makna prinsip demokrasi dan penjabaran prinsip demokrasi dalam pembentukan kebijakan daerah. Dalam Kajian ini manfaat penulisan adalah bermanfaat terhadap perkembangan ilmu hukum terkait dengan penjabaran prinsip demokrasi dalam pembentukan kebijakan daerah dan bermanfaat bagi kalangan praktisi terutama para perancang hukum yang terlibat dalam pembetukan kebijakan daerah.

\section{METODE PENELITIAN}

Dalam penelitian ini metode penelitian yang digunakan adalan metode penelitian normatif. Metode Penelitian Normatif adalah penelitian hukum yang mengkaji hukum tertulis dari berbagai aspek, yaitu aspek teori, sejarah, filosofis, lingkup dan materi, konsistensi, penjelasan umum dan pasal demi pasal, formalitas, dan kekeuasan mengikat suatu Undang-undang, serta bahasa hukum yang digunakan. Oleh karena itu penelitian hukum normative sering disebut penelitian hukum dogmatic atau penelitian hukum teoritis (dogmatic or theoretical law research) ${ }^{6}$. Bernard Arif Sidharta $^{7}$ juga menyebutkan bahwa penelitian hukum normatif merupakan penelitian dogmatika hukum. Soetandyo Wignjosoebroto ${ }^{8}$ menyebut peneltian normative sebagai penelitian doctrinal. Lebih lanjut ditegaskan bahwa metode penelitian doctrinal adalah bekerja untuk menemukan jawaban-jawaban yang benar dengan pembuktian kebenaran yang dicari dari preskripsi-preskripsi hukum yang tertulis di kitab undang-undang serta ajaran dan doktrin yang melandasinya. Penelitian ini bermaksud untuk menganalisis permasalahan hukum normative yaitu mengenai penjabaran prinsip demokrasi dalam pembentukan Kebijakan daerah Kabupaten Badung. Jenis pendekatan penelitian adalah sebagai langkah dalam pemecahan masalah (problem solution) ${ }^{9}$. Dalam penelitian ini metode pendekatan yang digunakan adalah pendekatan Peraturan Perundang-undangan (Statue approach) yaitu dengan menelaah Undang-undang dan regulasi bersangkutan dengan isu

6 Abdulkadir Muhammad, Hukum dan Penelitian Hukum, Bandung: PT Citra Aditya Bakti, 2004, hlm.101-102.

${ }^{7}$ Bernard Arif Sidharta, "Penelitian Hukum Normatif : Analisis Penelitian Filosofikal dan Dogmatikal", dalam Metode Penelitian Hukum Konstelasi dan Refleksi, Jakarta: Yayasan Obor Indonesia, 2009, hlm. 142.

"Soetandyo Wignjosoebroto, "Ragam-Ragam Penelitian Hukum" dalam Metode Penelitian Hukum Konstelasi dan Refleksi, Jakarta, Yayasan Obor Indonesia, 2009, hlm. 121.

${ }_{9}$ Abdulkadir Muhammad, 2004, op.cit, hlm.101-102

Anak Agung Istri Ari Atu Dewi; Luh Nila Winarni, Penjabaran Prinsip Demokrasi Dalam Pembentukan Kebijakan Daerah 
hukum dalam penelitian ini dan pendekatan filsafat (philosophicalapproach) ${ }^{10}$. Uraian metode pendekatan yang digunakan sebagai berikut :

1. Pendekatan Peraturan Perundang-undangan (Statue approach) digunakan untuk mengkaji peraturan perundang-undangan yang berkaitan dengan penjabaran prinsip demokrasi dalam pembentukan peraturan daerah.

2. Pendekatan filsafat (philosophicalapproach) digunakan untuk mengkaji landasan filosofis yang berkaitan dengan penjabaran prinsip demokrasi dalam pembentukan peraturan daerah.

Sumber bahan hukum yang digunakan dalam penelitian ini adalah sumber bahan hukum primer dan sumber bahan hukum sekunder. Bahan hukum pimer adalah bahan hukum yang otoritatif ${ }^{11}$. Bahan hukum primer yang digunakan dalam penelitian ini adalah UUD Negara Republik Indonesia Tahun 1945, UU Nomor 23 Tahun 2014 tentang Pemerintahan Daerah, UU Nomor 12 Tahun 2011 tentang Pembentukan Peraturan Perundang-undangan, Peraturan Menteri Dalam Negeri Nomor 1 Tahun 2014 tentang Pembentukan Produk Hukum Daerah, Peraturan Daerah Kabupaten Badung Nomor 15 Tahun 2013 tentang Perlindungan Perempuan dan Anak Korban Kekerasan dan Peraturan Daerah Kabupaten Badung Nomor 26 Tahun 2013 Tentang Rencana Tata Ruang Wilayah Kabupaten Badung Tahun 2013 - 2033 Selanjutnya bahan hukum sekunder yang digunakan adalah semua publikasi tentang hukum seperti buku-buku teks, jurnal hukum dan lain sebagainya. Dalam menganalisis bahan hukum, baik yang di dapat dari bahan hukum primer dan bahan hukum sekunder diolah dan dianalisis secara deskripsi untuk menguraikan bahan hukum yang telah dikumpulkan. Bahan hukum yang terkumpul baik itu peraturan perundang-undangan dan doktrin ataupun pendapat sarjana diinterpretasikan dengan menggunakan jenis-jenis penafsiran. Penafsiran yang digunakan adalah penafsiran sistimatis dan hermeneutika hokum. Selanjutnya dievaluasi untuk memberikan penilaian berupa tepat dan atau tidak tepat, setuju dan tidak setuju, benar atau salah, sah atau tidak sah oleh peneliti suatu pandangan, proposisi, pernyataan rumusan norma yang tertera dalam bahan hukum primer dilanjutkan dengan argumentasi sebagai hasil akhir untuk mendapatkan suatu simpulan dari permasalahan yang di bahas.

\section{HASIL DAN PEMBAHASAN}

\section{Makna prinsip demokrasi dalam pembentukan kebijakan daerah.}

10 Peter Mahmud Marzuki, 2005, Penelitian Hukum, Jakarta: Prenada Media, hlm.92.

${ }^{11}$ H Zainuddin Ali, 2009, Metode Penelitian Hukum, Jakarta: Sinar Grafika, hlm. 47.

Anak Agung Istri Ari Atu Dewi; Luh Nila Winarni, Penjabaran Prinsip Demokrasi Dalam Pembentukan Kebijakan Daerah 
Berbicara demokrasi maka tidak akan bisa lepas dari Negara hukum, terdapat korelasi antara demokrasi dengan Negara hukum. Menurut Franz Magnis Suseno sebagaimana dikutip oleh Abdul Aziz Hakim menayatakan bahwa Demokrasi yang bukan Negara hukum bukan demokrasi dalam arti sesungguhnya ${ }^{12}$. Pemahaman demokrasi sangat luas bukan saja hanya menyangkut soal politik melainkan termasuk peran serta masyarakat teruama dalam pembentukan kebijakan daerah. ${ }^{13}$

Demokrasi merupakan cara yang paling aman untuk mempertahankan, kontrol atas Negara dalam arti negara hukum harus ditopang dengan system demokrasi. Demokrasi merupakan ajaran yang menentukan bahwa sumber kekuasaan tertinggi atau kedaulatan dalam suatu Negara berada di tangan rakyat. Dengan demikian segala aturan dan kekuasaan yang dijalankan oleh Negara tidak boleh bertentangan dengan kehendak rakyat (hati nurani rakyat). Dalam alam demokrasi esensinya ada pada partisipasi rakyat atau partisipasi publik. Demokrasi juga sangat dipengaruhi oleh demokrasi lokal yaitu cerminan budaya politik suatu daerah. ${ }^{14}$

Dalam konteks perumusan kebijakan daerah, aspek filosofis menjadi hal penting. Aspek filosofis dijadikan pedoman dan landasan dalam pebentukan kebijakan daerah. ${ }^{15}$ partisipasi publik merupakan pentahapan yang harus dilakukan. Lebih lajut Philipus M. Haddjon ${ }^{16}$ menyatakan bahwa dalam konsep partisipasi publik, rakyat mempunyai hak untuk ikut memutuskan dalam proses pengambilan keputusan pemerintah. Hal ini mempunyai maksud, untuk memberikan ruang kepada masyarakat untuk ikut berpartisipasi dalam perumusan kebijakan daerah. Partisipasi Publik dapat dilakukan secara langsung atau tidak langsung. Partisipasi tidak langsung dalam perumusan kebijakan public tercakup dalam "representasi atau keterwakilan" yang dalam konteks pembentukan kebikajan public kekinian tidak relevan lagi, hal ini disebabkan karena kebijakan yang dihasilkan adalah tidak memberikan kepuasan kepada masyarakat, sehingga beralih pada partisipasi langsung dalam proses pembentukan Kebijakan daerah.

12 Abdul Aziz Hakim, Negara Hukum dan Demokrasi Di Indonesia, Yogyakarta: Pustaka Pelajar, 2011, hlm 160.

13 Rahman, M.. Demokrasi Dalam Filsafat Pendidikan Barat Dan Islam (Kajian Tentang Nilai-Nilai Demokrasi Dan Implementasinya Dalam Konteks Pendidikan Indonesia). Jurnal Cendekia, 3(2) (2018.

14 Fikri, M. S., \& Adytyas, N. O. Politik Identitas dan dan penguatan Demokrasi Lokal (Kekuatan Wong kito dalam demokrasi lokal), (2018).

15 Zaini, Z. D. Perspektif Hukum Sebagai Landasan Pembangunan Ekonomi Di Indonesia (Sebuah Pendekatan Filsafat). Jurnal Hukum, 28(2), (2019). hlm. 929-957.

16Philipus M. Haddjon, "Keterbukaan Pemerintahan Dalam Mewujudkan Pemerintahan Yang Demokratis", Pidato yang diucapkan dalam Lustrum III Ubhara Surya Pada tanggal 13 Juli 1997, hlm. 8.

Anak Agung Istri Ari Atu Dewi; Luh Nila Winarni, Penjabaran Prinsip Demokrasi Dalam Pembentukan Kebijakan Daerah 
Sebagaimana diketahui bersama bahwa kebijakan daerah baik yang berupa perda maupun perkada (peraturan kepala daerah) tidak bisa lepas dari penjabaran prinsip demokrasi yaitu partisipasi langsung ketika dalam perumusan kebijakan daerah. Dapat dipahami juga bahwa perumusan kebijakan daerah Kabupaten Badung juga memperhatikan dan melaksanakan partisipasi public. Hal ini dapat dilihat dalam proses pembentukan Perda Nomor 26 Tahun 2013 tentang Rencana Tata Ruang Wilayah Kabupaten Badung Tahun 20132033 dan Perda Nomor 15 Tahun 2013 tentang Perlindungan Perempuan dan Anak Korban Kekerasan. Dalam tataran Perkada, partisipasi public juga tidak boleh diabaikan, seperti dalam perumusan Peraturan Bupati Nomor 25 Tahun 2015 tentang Rencana Aksi Daerah (RAD) Pengembangan Kabupaten Layak Anak (KLA) Di Kabupaten Badung dan Peraturan Bupati Nomor 83 Tahun 2013 tentang Penyelengaraan Tanggung Jawab Sosial Perusahaan Di Kabupaten Badung. Mengingat pentingnya partisipasi publik dalam pembentukan kebijakan daerah merupakan salah satu ciri good governance. Lebih lanjut UNDP (United NationsDevelopment Programme) sebagaimana dikutip I Gusti Ngurah Wairocana menyatakan bahwa good governance, adalah suatu hubungan sinergis atara Negara sektor swasta (pasar) dan masyarakat yang berlandaskan pada Sembilan karakteristik yaitu : partisipasi, rule of law, transparansi, sikap responsive, berorientasi konsensus, kesejahteraan/kebersamaan, efektif dan efesien, akuntabilitas dan visi strategis. ${ }^{17}$

Merujuk salah satu karakteristik good governance yaitu partisipasi merupakan penjabaran dari prinsip demokrasi. Menelaah prinsip demokrasi berarti menelaah asas hukum. Dalam pembentukan kebijakan daerah, asas hukum merupakan suatu hal yang penting untuk di kaji. Kebiajakan daerah yang dibentuk wajib berdasarkan pada asas-asas hukum agar sesuai dengan cita hukum dan kebutuhan hidup bersama. Asas hukum bukan norma konkrit, melainkan asas hukum merupakan aturan dasar yang melatarbelakangi lahirnya norma konkrit. Oleh karena itu asas hukum merupakan jantungnya hukum (pemandu dalam pembentukan peraturan daerah).

Prinsip atau asas pembentukan peraturan perundang-undangan yang baik, sebagaimana yang dikehendaki oleh tujuan hukum, yakni adanya keadilan dan kepastian hukum, adalah telah dipositipkan dalam UndangUndang Nomor 12 Tahun 2011. Untuk mencapai suatu keadilan dan kepastian hukum, John Austin dengan analytical legal positivism-nya memberikan ajaran positivisme yuridis bahwa hukum merupakan perintah-perintah dalam bentuk

17 I Gusti Ngurah Wairocana, 2008, "Implementasi Good Governance Dalam Legislasi Daerah" Pidato Pengukuhan jabatan Guru Besar Tetap dalam Bidang Ilmu Hukum Administrasi PAda Fakultas Hukum Universitas Udayana, Tanggal 22 November 2008, hlm. 12.

Anak Agung Istri Ari Atu Dewi; Luh Nila Winarni, Penjabaran Prinsip Demokrasi Dalam Pembentukan Kebijakan Daerah 
peraturan-peraturan formal dari penguasa yang sah suatu negara dan keberlakuannya dipaksakan,apabila melanggar, maka dijatuhi sanksi. Oleh sebab itu unsur-unsur hukum menurut Austin antara lain: (1) penguasa; (2) perintah; (3) kewajiban; dan (4) sanksi ${ }^{18}$. Senada dengan Austin, Hans Kelsen dalam pure theory of law menyebutkan "law is coercive order, that is normative order that attempts to bring about a certain behavior by attaching to the opposite behavior a socially organized coercive act"19.

Berdasarkan Teori negara hukum demokrasi, pemaknaan prinsip demokrasi dalam pembentukan kebijakan daerah adalah penting untuk mengkaji prinsip atau asas demokrasi terlebih dahulu, sebelum perumusan pada norma pasal. Sebagaimana telah dirumuskan sebelumnya bahwa prinsip demokrasi dan konsep negara hukum merupakan dua hal yang dicita-citakan. Refleksi prinsip demokrasi dan konsep negara hukum dapat dilihat dari hubungan korelasi yang erat diantaranya. Bahwa suatu negara hukum yang bercitakan keadilan adalah mendasarkan pada prinsip persamaan dihadapan hukum. Negara hukum secara ideal merupakam negara hukum yang berdasarkan demokrasi (negara hukum demokrasi). Oleh karena itu Kebijakan daerah harus dibuat secara demokrasi dan merefleksikan nilai-nilai demokrasi.

Di Indonesia keadilan itu digambarkan dalam Pancasila sebagai dasar negara, yaitu keadilan sosial bagi seluruh rakyat Indonesia. Dalam keadilan tersebut juga didasai oleh Ketuhanan yang maha esa sebagai wujud sila 1, didasari dengan sila ke 2 , sila ke 3 , sila ke 4 dan sila ke 5 . Nilai-nilai keadilan tersebut merupakan suatu dasar yang harus diwujudkan dalam kehidupan bermegara. Hukum sangat erat kaitannya dengan keadilan. Sebagaimana disebut oleh Agus Santoso bahwa hukum berasal dari kehendak yuridis dan politis yang mengatur relasi-relasi melalui norma-norma hukum yang menetapkansuatu tatanan sosial yang adil. Bahwa hukum mewajibkan secara etis dan yuridis, sebab hukum merupakan keadilan ${ }^{20}$. Lebih lanjut dikatakan bahwa hukum dan moral mempunyai hubungan yang erat. Hukum harus sesuai dengan prinsip-prinsip moral. Moral merupakan tahapan untuk mencapai keadilan dan keadilan terefleksi di dalam hukum. Hal ini menandakan bahwa

18 A Mukthie Fadjar, 2014, Teori-Teori Hukum Kontenporer, Malang, Setara Press, hlm.10.

19 Hans Kelsen, Pure Theory of Law, The Lawbook Exchange, LTD, Clark New jersey, 2005, hlm. 62.

${ }^{20}$ H.M.Agus Santoso, Hukum, Moral \&Keadilan Sebuah Kajian Filsafat Hukum, Prenada Media Group, 2012, hlm, 92.

Anak Agung Istri Ari Atu Dewi; Luh Nila Winarni, Penjabaran Prinsip Demokrasi Dalam Pembentukan Kebijakan Daerah 
hukum juga merupakan moral. Hans Kelsen juga menyatakan "law is viewed as norm, just as morality is" 21

Dalam pembentukan kebijakan daerah, refleksi nilai demokrasi dapat dilihat dalam asas keterbukaan sebagai salah satu asas dalam meteri muatan formal yang diatur dalam Pasal 5 UU No. 12 tahun 2011 tentang Pembentukan Peraturan Perundang-undangan. Menurut M Hadjon, keterbukaan baik itu "openheid maupun openbaarheid"22hal ini sangat penting dalam pelaksanaan pemerintah yang baik dan demokratis. Openheid mempuyai arti suatu sikap mental berupa kesediaan untuk memberikan informasi dan kesediaan untuk menerima pendapat orang lain sedangkan openbaarheid adalah menunjukan suatu keadaan adanya keterbukaan.

Selanjutnya joko widodo ${ }^{23}$ menyatakan bahwa keterbukaan tersebut mengacu pada terbukanya kesempatan bagi rakyat untuk mengajukan tanggapan dan kritik terhadap pemerintah yang dinilai tidak transparan.

Terkait dengan pembentukan kebijakan daerah asas keterbukaan sebagaimana telah dipaparkan di atas mengandung arti membuka diri terhadap hak masyarakat untuk memperoleh informasi yang benar, jujur dan tidak diskriminatif baik mulai dari perencanaan, persiapan, penyusunan dan tahap pembahasan serta seluruh lapisan masyarakat mempunyai kesempatan yang seluas-luasnya untuk memberikan masukan dalam proses pembentukan kebijakan daerah. Demikian pula ketika merefleksikan nilai nilai demokrasi dalam norma pasal tetap perpedoman pada aturan hukum nomatif yaitu mendasarkan pada konstitusi, undang-undang dan aturan hukum lainya. Hal ini mempunyai arti bahwa demokrasi yang dimaksud adalah demokrasi prosedural, yang oleh jimly asshiddiqie disebut demokrasi konstitusional (constitutional democracy) atau demokrasi berdasarkan atas hukum ${ }^{24}$. Oleh karena itu dapat dipahami bahwa makna dari prinsip demokrasi dalam pembentukan kebijakan daerah adalah asas keterbukaan yang partisipatif.

\section{Penjabaran Prinsip Demokrasi Dalam Pembentukan Kebijakan Daerah.}

${ }^{21}$ Hans Kelsen, Introduction To The Problems Of Legal Theory, A translation of the First Edition of the Reine Rechtslehre or Pure Theory of law, Oxford University Press, Walton Street, Oxford ox2 6 dp, Oxford New York Toronto, 1992, hlm 23.

22 Philipus M Hadjon, "Keterbukaan Pemerintahan Dalam Mewujudkan pemerintahan Yang Demokratis (suatu Pemikiran dalam usaha meningkatkan perwujudan asas demokrasi dalam penyelenggaraan pemerintahan di Indonesia)", Pidato dalam rangka Lustrum III Ubhara Surya di Surabaya, 1999, hlm. 4.

23 Joko Widodo, Good Governance Telaah dari Dimensi Akuntabilitas dan Kontrol

Birokrasi Pada Era Desentralisasi dan Otonomi Daerah, Surabaya, Penerbit Insan Cendikia, 2001, hlm. 28.

24 Janedjri M. Gaffar, Op.cit, hlm. 61.

Anak Agung Istri Ari Atu Dewi; Luh Nila Winarni, Penjabaran Prinsip Demokrasi Dalam Pembentukan Kebijakan Daerah 
Berbicara tentang penjabaran berarti berbicara tentang implementasi prinsip demokrasi dalam proses pembentukan kebijakan daerah. Sebagaimana disebutkan oleh jimly asshiddiqie yang menyatakan demokrasi konstitusional yang mempunyai arti bahwa negara berdasarkan atas undang-undang dan aturan hukum lainnya. Aturan hukum tersebut memiliki fungsi membatasi kekuasaan pemerintah sehingga kekuasaan tersebut tidak bersifat sewenangwenang, dengan demikian hak-hak warga Negara lebih terlindungi. Selanjutnya dalam sebuah Negara demokrasi, wujud demokrasi adalah partisipasi masyarakat. Partisipasi tersebut dibangun berdasarkan kebebasan berkumpul dan menyatakan pendapat serta kapasitas untuk berpartisipasi secara konstruktif (pembentukan kebijakan daerah).

Terkait dengan pembentukan kebijakan daerah ada beberapa proses pentahapan pembentukan sampai menjadi suatu peraturan daerah. Proses pembentukan tersebut pada dasarnya dimulai dari proses perencanaan, perancangan, perumusan, pembahasan, pengesahan, pengundangan, penyebarluasan dan evaluasi. Secara yuridis, proses pembentukan tersebut harus sesuai dengan Undang-Undang Nomor 12 tahun 2011 tentang Pembentukan Peraturan Perundang-undangan, Undang-Undang Nomor 23 Tahun 2014 dan Peraturan Menteri Dalam Negeri Nomor 1 Tahun 2014. Sebagai wujud penjabaran prinsip demokrasi dapat dilihat dalam Bab XI Partisipasi Masyarakat khususnya Pasal 96 dan diatur dalam Undang-Undang Nomor 23 tahun 2014 tentang Pemerintah Daerah dalam Bab XIV Partisipasi Masyarakat khususnya Pasal 354 serta Bab X dalam Pasal 110 Permendagri No.1 Tahun 2014 yang khusus mengatur Partisipasi Masyarakat. Untuk memudahkan melihat penjabaran prinsip demokrasi dalam peraturan perundang-undangan, maka dibuatkan dalam bentuk tabel:

\begin{tabular}{|c|c|c|c|}
\hline $\begin{array}{l}\text { UU Nomor } 12 \text { tahun } \\
2011 \text { tentang } \\
\text { Pembentukan } \\
\text { Peraturan Perundang- } \\
\text { Undangan }\end{array}$ & $\begin{array}{l}\text { UU Nomor } 23 \text { Tahun } \\
2014 \text { tentang } \\
\text { Pemerintah Daerah }\end{array}$ & $\begin{array}{l}\text { Permendagri } \\
\text { No.1 Tahun } \\
2014 \text { tentang } \\
\text { Pembentukan } \\
\text { Produk Hukum } \\
\text { Daerah }\end{array}$ & Keterangan \\
\hline $\begin{array}{l}\text { Pasal } 96 \\
\text { (1) Masyarakat } \\
\text { berhak } \\
\text { memberikan } \\
\text { masukan } \\
\text { secara lisan } \\
\text { dan/atau } \\
\text { tertulis dalam }\end{array}$ & $\begin{array}{l}\text { Pasal } 354 \\
\text { (1) Dalam } \\
\text { penyelenggaraan } \\
\text { Pemerintahan } \\
\text { Daerah, } \\
\text { Pemerintah } \\
\text { Daerah } \\
\text { mendorong }\end{array}$ & $\begin{array}{l}\text { Pasal } 110 \\
\text { (1) Masyarakat } \\
\text { berhak } \\
\text { memberikan } \\
\text { masukan } \\
\text { secara lisan } \\
\text { dan/atau } \\
\text { tertulis dalam }\end{array}$ & $\begin{array}{l}\text { Prinsip } \\
\text { demokrasi } \\
\text { telah } \\
\text { dijabarkan } \\
\text { pada Bab } \\
\text { Partisipasi } \\
\text { Masyarakat } \\
\text { dalam }\end{array}$ \\
\hline
\end{tabular}

Anak Agung Istri Ari Atu Dewi; Luh Nila Winarni, Penjabaran Prinsip Demokrasi Dalam Pembentukan Kebijakan Daerah 


\begin{tabular}{|c|c|c|c|c|c|c|}
\hline (4) & $\begin{array}{l}\text { Pembentukan } \\
\text { Peraturan } \\
\text { Perundang- } \\
\text { undangan. } \\
\text { Masukan } \\
\text { secara lisan } \\
\text { dan/atau } \\
\text { tertulis } \\
\text { sebagaimana } \\
\text { dimaksud pada } \\
\text { ayat (1) dapat } \\
\text { dilakukan } \\
\text { melalui: } \\
\text { a. rapat } \\
\quad \text { dengar } \\
\quad \text { pendapat } \\
\quad \text { umum; } \\
\text { b. kunjungan } \\
\quad \text { kerja; } \\
\text { c. sosialisasi; } \\
\quad \text { dan/atau } \\
\text { d. seminar, } \\
\quad \text { lokakarya, } \\
\quad \text { dan/atau } \\
\quad \text { diskusi. } \\
\text { Masyarakat } \\
\text { sebagaimana } \\
\text { dimaksud pada } \\
\text { ayat (1) adalah } \\
\text { orang } \\
\text { perseorangan } \\
\text { atau kelompok } \\
\text { orang yang } \\
\text { mempunyai } \\
\text { kepentingan } \\
\text { atas substansi } \\
\text { Rancangan } \\
\text { Peraturan } \\
\text { Perundang- } \\
\text { undangan. } \\
\text { Untuk } \\
\text { memudahkan } \\
\text { masyarakat } \\
\text { dalam } \\
\text { memberikan } \\
\text { masukan }\end{array}$ & (2) & 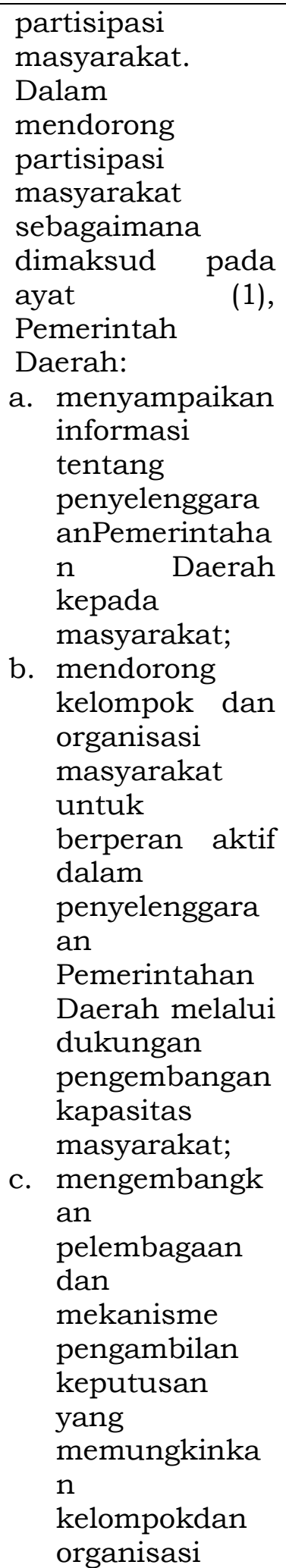 & (2) 1 & $\begin{array}{l}\text { pembentukan } \\
\text { Perda, } \\
\text { Perkada, PB } \\
\text { KDHdan/ata } \\
\text { u Peraturan } \\
\text { DPRD. } \\
\text { Masukan } \\
\text { secara lisan } \\
\text { dan/atau } \\
\text { tertulis } \\
\text { sebagaimana } \\
\text { dimaksud } \\
\text { pada ayat (1) } \\
\text { dapat } \\
\text { dilakukan } \\
\text { melalui: } \\
\text { a. Rapat } \\
\text { dengar } \\
\text { pendapat } \\
\text { umum; } \\
\text { b. Kunjunga } \\
\text { n kerja; } \\
\text { c. Sosialisasi } \\
\text {; } \\
\text { dan/atau } \\
\text { d. Seminar, } \\
\text { lokakarya } \\
\text { dan/atau } \\
\text { diskusi. } \\
\text { Masyarakat } \\
\text { sebagaimana } \\
\text { dimaksud } \\
\text { pada ayat (1) } \\
\text { merupakan } \\
\text { orang } \\
\text { perseorangan } \\
\text { atau } \\
\text { kelompok } \\
\text { orang yang } \\
\text { mempunyai } \\
\text { kepentingan } \\
\text { atas } \\
\text { substansi } \\
\text { Rancangan } \\
\text { Perda, } \\
\text { Perkada, PB }\end{array}$ & $\begin{array}{l}\text { Peraturan } \\
\text { Perundang- } \\
\text { undangan. }\end{array}$ \\
\hline
\end{tabular}

Anak Agung Istri Ari Atu Dewi; Luh Nila Winarni, Penjabaran Prinsip Demokrasi Dalam Pembentukan Kebijakan Daerah 


\begin{tabular}{|c|c|c|c|c|}
\hline $\begin{array}{l}\text { secara lisan } \\
\text { dan/atau } \\
\text { tertulis } \\
\text { sebagaimana } \\
\text { dimaksud pada } \\
\text { ayat (1), setiap } \\
\text { Rancangan } \\
\text { Peraturan } \\
\text { Perundang- } \\
\text { undangan } \\
\text { harus dapat } \\
\text { diakses dengan } \\
\text { mudah oleh } \\
\text { masyarakat. }\end{array}$ & (3) & 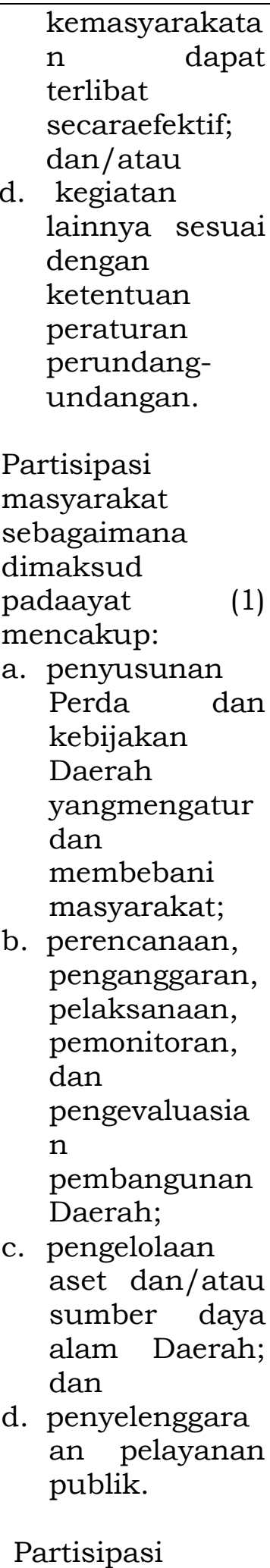 & $\begin{array}{l}\text { KDHdan/ata } \\
\text { u Peraturan } \\
\text { DPRD. } \\
\text { (4) Untuk } \\
\text { memeudahka } \\
\text { n masyarakat } \\
\text { dalam } \\
\text { memberikan } \\
\text { masukan } \\
\text { secara lisan } \\
\text { dan/atau } \\
\text { tertulis } \\
\text { sebagaimana } \\
\text { dimaksud } \\
\text { pada ayat (1), } \\
\text { setiap } \\
\text { Rancangan } \\
\text { Perda, } \\
\text { Perkada, PB } \\
\text { KDHdan/ata } \\
\text { u Peraturan } \\
\text { DPRD harus } \\
\text { dapat diakses } \\
\text { dengan } \\
\text { mudah oleh } \\
\text { masyarakat. }\end{array}$ & \\
\hline
\end{tabular}

Anak Agung Istri Ari Atu Dewi; Luh Nila Winarni, Penjabaran Prinsip Demokrasi Dalam Pembentukan Kebijakan Daerah 


\begin{tabular}{|c|c|c|}
\hline de & $\begin{array}{l}\text { masyarakat } \\
\text { sebagaimana } \\
\text { dimaksud pada } \\
\text { ayat (3) } \\
\text { dilakukan dalam } \\
\text { bentuk: } \\
\text { a. konsultasi } \\
\text { publik; } \\
\text { b. musyawarah; } \\
\text { c. kemitraan; } \\
\text { d. penyampaian } \\
\text { aspirasi; } \\
\text { e. pengawasan; } \\
\text { dan/atau } \\
\text { f. keterlibatan lain } \\
\text { sesuai dengan } \\
\text { ketentuan } \\
\text { peraturan } \\
\text { perundang- } \\
\text { undangan. }\end{array}$ & \\
\hline
\end{tabular}

Penjabaran prinsip demokrasi secara yuridis dalam peraturan perundang-undangan di atas menunjukkan bahwa partisipasi masyarakat dalam proses pembentukan kebijakan daerah tidak boleh diabaikan.

Sebagaimana ketika dalam pembentukan kebijakan Daerah yang berupa Peraturan Daerah Kabupaten Badung Nomor 15 Tahun 2013 Tentang Perlindungan Perempuan Dan Anak Korban Kekerasan. Dalam proses pembentukannya, partisipasi public merupakan suatu pentahapan yang penting untuk dilaksanakan dalam mewujudkan demokrasi dan peraturan daerah yang baik dan sesuai dengan kebutuhan masyarakat. Kebijakan daerah yang dibentuk mesti menyerap pendapat-pendapat atau aspirasi masyarakat melalui mekanisme partisipasi langsung. Dalam pembentukan Perda Nomor 15 Tahun 2013 tentang Perlindungan Perempuan Dan Anak Korban Kekerasan, Peraturan Daerah Kabupaten Badung Nomor 26 Tahun 2013 Tentang Rencana Tata Ruang Wilayah Kabupaten Badung Tahun 2013 - 2033, makanisme penyaluran aspirasi masyarakat (partisipasi public) dapat dilakukan oleh DPRD (yang merupakan perwakilan masyarakat) atau penyaluran aspirasi secara langsung oleh masyarakat terkait dengan pokok-pokok pemikiran yang merupakan materi muatan perda tersebut. Penyaluran aspirasi masyarakat terhadap rancangan peraturan daerah dapat dilakukan dengan hearing (rapat dengan pendapat) dan konsultasi public. Rapat dengar pendapat merupakan rapar antara DPRD/Komisi/Gabungan Komisi/Panitia khusus dengan

Anak Agung Istri Ari Atu Dewi; Luh Nila Winarni, Penjabaran Prinsip Demokrasi Dalam Pembentukan Kebijakan Daerah 
Lembaga/Badan/Organisasi Kemasyarakatan. Hal ini mempunyai arti bahwa masyarakat yang terorganisasi baru dapat terlibat di dalam Rapat Dengar Pendapat, sedangkan masyarakat yang tidak terorganiasikan dalam suatu organisasi kemasyarakatan tidak diikutsertakan dalam rapat dengar pendapat. Ini menunjukan hak masyarakat untuk berpartisipasi.

Sebagaimana disebutkan oleh Jazim Hamidi25 bahwa dalam konteks ini partisipasi publik dapat dikatakan sebagai alat komunikasi. Hal ini dapat pahami bahwa konsep ini melihat partisipasi sebagai alat komunikasi bagi pemerintah dalam arti sebagai pelayan rakyat untuk mengetahui keinginan rakyat. Seturut dengan hal di atas dalam pendekatan legalistik bahwa pelaksanaan kebijakan tersebut dinyatakan "people have an absolute duty to obey the law"26 dalm arti rakyat punya kewajiban yang tidak bisa di tawar (mutlak) untuk memenuhi undang-undang maka usaha untuk menjadikan masyarakat tahu tentang kebijakan yang dibentuk. Oleh karena itu, respek masyarakat terhadap keputusan-keputusan pemerintah terkait dengan pembentukan kebijakan daerah dapat dilakukan melalui partisipasi aktif dalam konteks pembentukan kebijakan daerah. Partisipasi masyarakat dapat dikatakan kunci kesuksesan suatu otonomi di daerah. ${ }^{27}$

Dalam teori partisipasi menurut Sherry Arnstein 28 dalam Aladder of Citizen Participation membuat skema 8 (delapan) tingkat partisipasi rakyat dalam merumuskan kebijakan. Tingkatan partisipasi masyarakat tersebut dapat dilihat dalam tabel yaitu :

\begin{tabular}{|l|l|}
\hline Pertama & $\begin{array}{l}\text { Kontrol warga negara (citizen control), pada tahap ini partisipasi } \\
\text { sudah mencapai tataran dimana publik berwenang memutus, } \\
\text { melaksanakan dan mengawasi pengelooan sumber daya alam. }\end{array}$ \\
\hline Kedua & $\begin{array}{l}\text { Delegasi kewenangan (delegate power), disini kewenangan } \\
\text { masyarakat lebih besar dari pada paenyelenggara negara dalam } \\
\text { merumuskan kebijakan. }\end{array}$ \\
\hline Ketiga & $\begin{array}{l}\text { Kemitraan (partnership), dalam hal ini ada keseimbangan kekuatan } \\
\text { relatif antara masyarakat dan pemegang kekuasaan untuk } \\
\text { merencanakan dan mengambil keputusan bersama-sama. }\end{array}$ \\
\hline
\end{tabular}

25Jazim Hamidi, Revolusi Hukum Indonesia: Makna, Kedudukan dan Implikasi Hukum Naskah Proklamasi 17 Agustus 1945 dalam Sistem Ketatanegaraan RI, Jakarta, Konstitusi Press dan Yogyakarta, Citra Media, 2006, hlm. 51

${ }^{26}$ M. Irfan Islamy, 1997, Prinsip-Prinsip Perumusan Kebijaksanaan Negara, Jakarta, Bumi Aksara hlm. 108.

27 Lambajang, A. A., Saerang, D. P., \& Morasa, J. Pengaruh Pengetahuan Tentang Anggaran, Partisipasi Masyarakat, Transparansi Kebijakan Publik, Dan Akuntabilitas Publik Terhadap Pengawasan Keuangan Daerah Pada Dewan Perwakilan Rakyat Daerah di Wilayah Sulawesi Utara. Jurnal Riset Akuntansi Dan Auditing" Goodwill", 9(1). (2018).

${ }^{28}$ Sirajuddin, Didik Sukrino dan Winardi, Hukum Pelayanan Publik Berbasis Partisipasi dan Keterbukaan Informasi, Malang, Setara Press, 2011, hlm.173.

Anak Agung Istri Ari Atu Dewi; Luh Nila Winarni, Penjabaran Prinsip Demokrasi Dalam Pembentukan Kebijakan Daerah 


\begin{tabular}{|l|l|}
\hline & $\begin{array}{l}\text { Tingkatan ke tiga ini mengakui eksistensi hak masyarakat untuk } \\
\text { ikut serta dalam pembentukan Undang-undang dalam konteks ini } \\
\text { (kebijakan daerah). }\end{array}$ \\
\hline Keempat & $\begin{array}{l}\text { Peredaman (Placation), merupakan partisipasi semu, dalam arti } \\
\text { rakyat sudah memiliki pengaruh terhadap kebijakan tapi bila } \\
\text { akhirnya terjadi voting pengambilan keputusan akan tampak } \\
\text { sejatinya keputusan ada ditangan negara, sedangkan kontrol dari } \\
\text { rakyat tidak menentukan. }\end{array}$ \\
\hline Kelima & $\begin{array}{l}\text { Konsultasi (consultation), pada tingkat ini rakyat di dengar } \\
\text { pendapatnya lalu disimpulkan, masyarakat telah berpartisipasi } \\
\text { dalam pembentukan peraturan perundang-undangan. }\end{array}$ \\
\hline Keenam & $\begin{array}{l}\text { Penginformasian (Informing), dapat dipahami masyarakat sekedar } \\
\text { diberi tahu akan adanya peraturan perundang-undangan, tidak } \\
\text { peduli apakah masyarakat pahamterhadap informasi tersebut. }\end{array}$ \\
\hline Ketujuh & $\begin{array}{l}\text { Terapi (Therapy), dapat dipahami bahwa masyarakat korban } \\
\text { kebijakan dianjurkan mengadu kepada pihak yang berwenang } \\
\text { namun tidak jelas pengaduan dan tidak ditindak lanjuti. }\end{array}$ \\
\hline $\begin{array}{l}\text { Kedelapa } \\
\mathrm{n}\end{array}$ & $\begin{array}{l}\text { Manipulasi (Manipulation), dapat dipahami bahwa lembaga negara } \\
\text { melakukan pembinaan terhadap kelomppok kelompok masyarakat } \\
\text { untuk seolah-olah berpartisipasi padahal sejatinya yang terjadi } \\
\text { adalah kooptasi dan represi penguasa. }\end{array}$ \\
\hline
\end{tabular}

Merujuk teori partisipasi Arnstein, maka menurut Wilcok ${ }^{29}$ sebagaimana dikutip oleh Sirajuddin dkk membedakan level (tingkatan) partisipasi public menjadi 5 (lima) jenis yaitu (1) pemberian informasi, (2) konsultasi, (3) pembuatan keputusan bersama, (4) melakukan tindakan bersama. Selanjutnya Wilcok juga menyatakan, pada tingkat mana partisipasi public akan dilakukan?, hal ini sangat tergantung pada kepentingan apa yang hendak dicapai. Untuk pengambilan kebijakan yang strategis yang mempengaruhi hajat hidup orang banyak tentu masyarakat harus dilibatkan secara penuh. Sementara dalam pengambilan keputusan yang bersifat teknis cukup hanya pemberian informasi kepada masyarakat.

Dalam konteks partisipasi publik dalam pembentukan Perda Nomor 15 Tahun 2013 Tentang Perlindungan Perempuan Dan Anak Korban Kekerasan dan Peraturan Daerah Kabupaten Badung Nomor 26 Tahun 2013 Tentang Rencana Tata Ruang Wilayah Kabupaten Badung Tahun 2013 - 2033, telah melibatkan masyarakat baik dalam proses perencanaan, pembentukan dan pengawasan. Dalam proses pembentukan perda dimaksud, maka partisipasi public tercermin dalam proses konsultasi public, sebagaimana disebutkan dalam teori partisipasi menurut Arnstein dan Wilcok. Dalam konsultasi public

${ }^{29} \mathrm{Ibid}$, hlm. 173.

Anak Agung Istri Ari Atu Dewi; Luh Nila Winarni, Penjabaran Prinsip Demokrasi Dalam Pembentukan Kebijakan Daerah 
Rancangan Peraturan Daerah tentang Perlindungan Perempuan Dan Anak Korban Kekerasan telah dilakukan beberapa kali kosultasi publik yang melibatkan masyarakat yang terkait, yaitu LSM, Lembaga penggiat perlindungan perempuan, Lembaga penggiat perlindungan Anak, Pemerintah dan DPRD. Hal ini menunjukkan bahwa pentahapan konsultasi public secara langsung dalam konteks pembentukan perda dimaksud sudah berjalan dengan baik. Partisipasi public secara langsung akan membawa tiga dampak penting yaitu : memperjelas apa yang dikehendaki oleh masyarakat, memberi nilai tambah pada legitimasi rumusan perencanaan dan meningkatkan kesadaran dan keterampilan politik masyarakat. Makna penting partisipasi adalah dapat dilihat dari fungsinya. Fungsi pertama adalah sebagai sarana pembelajaran sukarela kepada masyarakat tentang berbagai masalah public kemasyarakatan dan fungsi lainnya adalah sebagai sarana untuk menampilkan keseimbangan kekuasaan antara masyarakat dan pemerintah sehingga kepentingan dan pengetahuan masyarakat dapat terserap dalam agenda pemerintahan.

Lebih lanjut keterlibatan aspirasi masyarakat secara normative telah juga diatur dalam kebijakan-kebijakan daerah sebagaimana dapat dilihat dalam Perda Nomor 15 Tahun 2013, sehinga penjabaran prinsip demokrasi dalam Perda Nomor 15 Tahun 2013 Tentang Perlindungan Perempuan Dan Anak Korban Kekerasan diatur dalam Bab XI Pasal 16 tentang Partisipasi Masyarakat dan Peraturan Daerah Kabupaten Badung Nomor 26 Tahun 2013 Tentang Rencana Tata Ruang Wilayah Kabupaten Badung Tahun 2013 - 2033 khususnya Bab XII Hak, Kewajiban Dan Peran Masyarakat Bagian Ketiga Peran Masyarakat Pasal 109 Norma Pasal di atas dapat dilihat dalam Tabel berikut :

\begin{tabular}{|c|c|c|}
\hline $\begin{array}{lr}\text { Peraturan } & \text { Daerah } \\
\text { Kabupaten Badung } & \text { Nomor } \\
15 \text { Tahun 2013 } & \text { Tentang } \\
\text { Perlindungan Perempuan } \\
\text { Dan Anak } & \text { Korban } \\
\text { Kekerasan } & \\
\end{array}$ & $\begin{array}{l}\text { Peraturan Daerah Kabupaten } \\
\text { Badung Nomor } 26 \text { Tahun } 2013 \\
\text { Tentang Rencana Tata Ruang } \\
\text { Wilayah Kabupaten Badung } \\
\text { Tahun } 2013-2033\end{array}$ & Keterangan \\
\hline $\begin{array}{l}\text { BAB XI } \\
\text { PERAN SERTA MASYARAKAT } \\
\text { Pasal } 16 \\
\text { (1) Dalam menyelenggarakan } \\
\text { Perlindungan terhadap } \\
\text { Perempuan dan Anak } \\
\text { Korban Kekerasan, } \\
\text { masyarakat dapat: }\end{array}$ & $\begin{array}{c}\text { BAB XII } \\
\text { HAK, KEWAJIBAN DAN PERAN } \\
\text { MASYARAKAT } \\
\text { Bagian Ketiga } \\
\text { Peran Masyarakat } \\
\text { Pasal } 109 \\
\\
\text { (1) Penyelenggaraan Penataan } \\
\text { Ruang dilakukan oleh } \\
\text { Pemerintah Daerah dengan }\end{array}$ & $\begin{array}{l}\text { Secara } \\
\text { normative, } \\
\text { prinsip } \\
\text { demokrasi } \\
\text { telah } \\
\text { dijabarkan } \\
\text { pada Bab } \\
\text { tersendiri } \\
\text { dalam }\end{array}$ \\
\hline
\end{tabular}

Anak Agung Istri Ari Atu Dewi; Luh Nila Winarni, Penjabaran Prinsip Demokrasi Dalam Pembentukan Kebijakan Daerah 


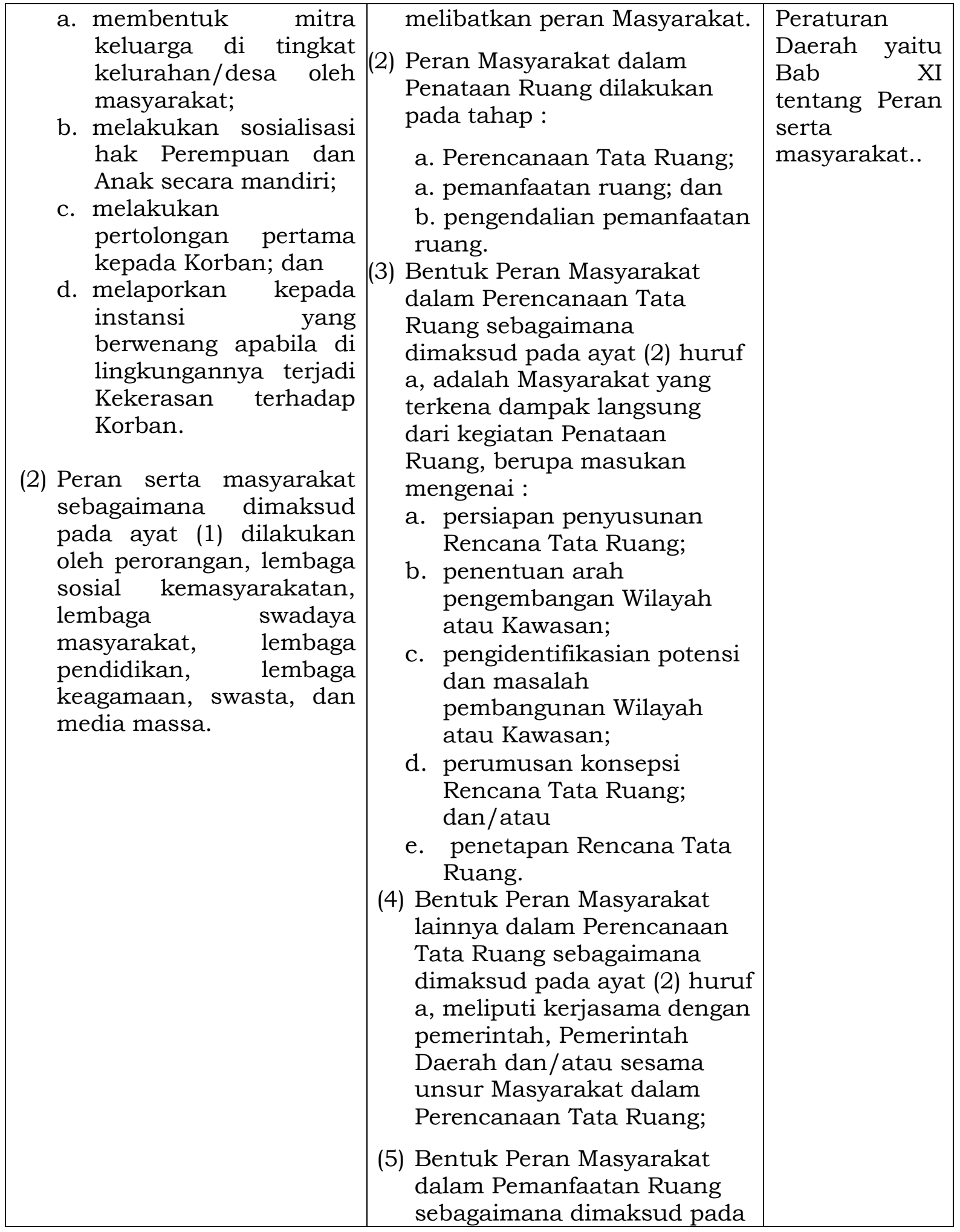

Anak Agung Istri Ari Atu Dewi; Luh Nila Winarni, Penjabaran Prinsip Demokrasi Dalam Pembentukan Kebijakan Daerah 


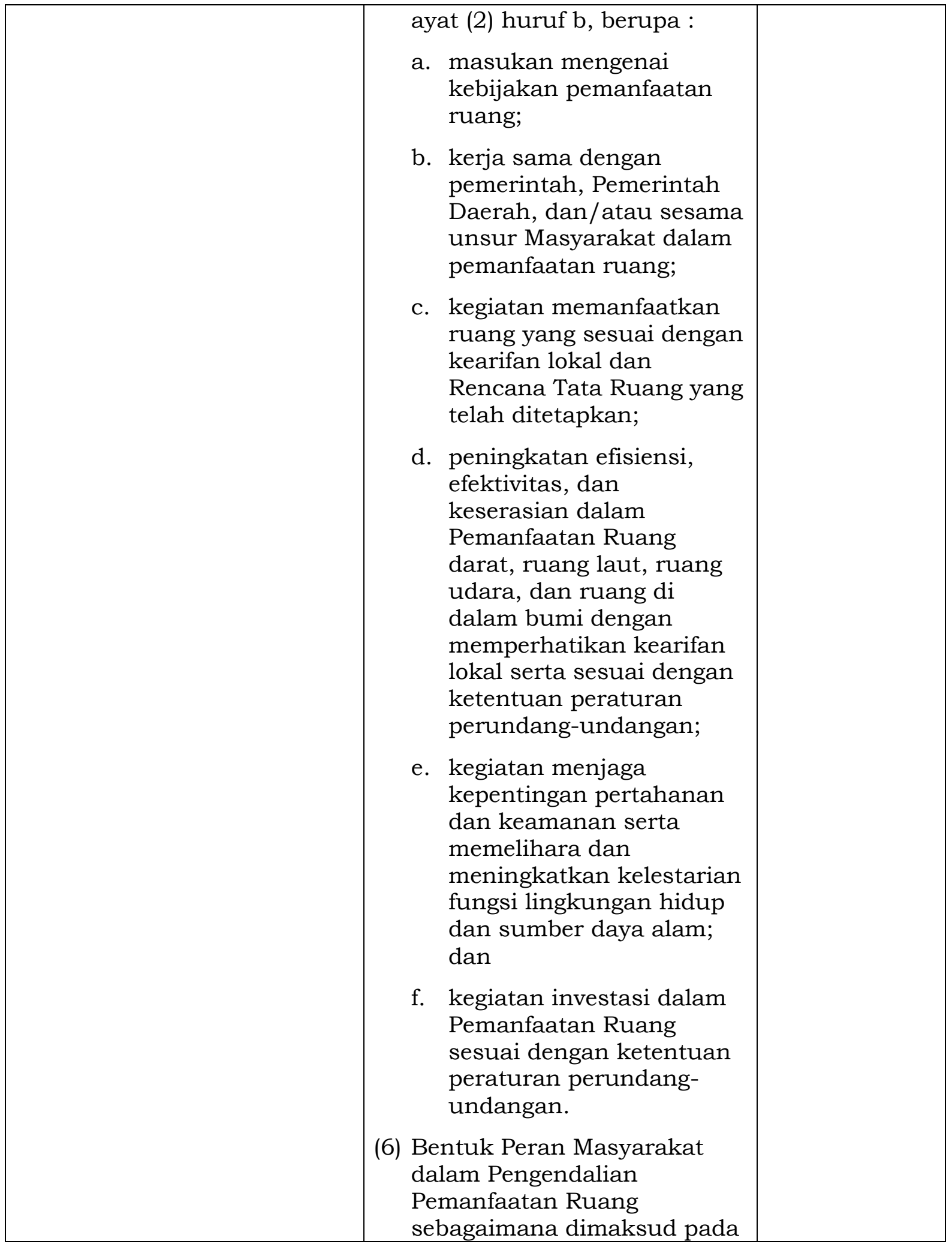

Anak Agung Istri Ari Atu Dewi; Luh Nila Winarni, Penjabaran Prinsip Demokrasi Dalam Pembentukan Kebijakan Daerah 


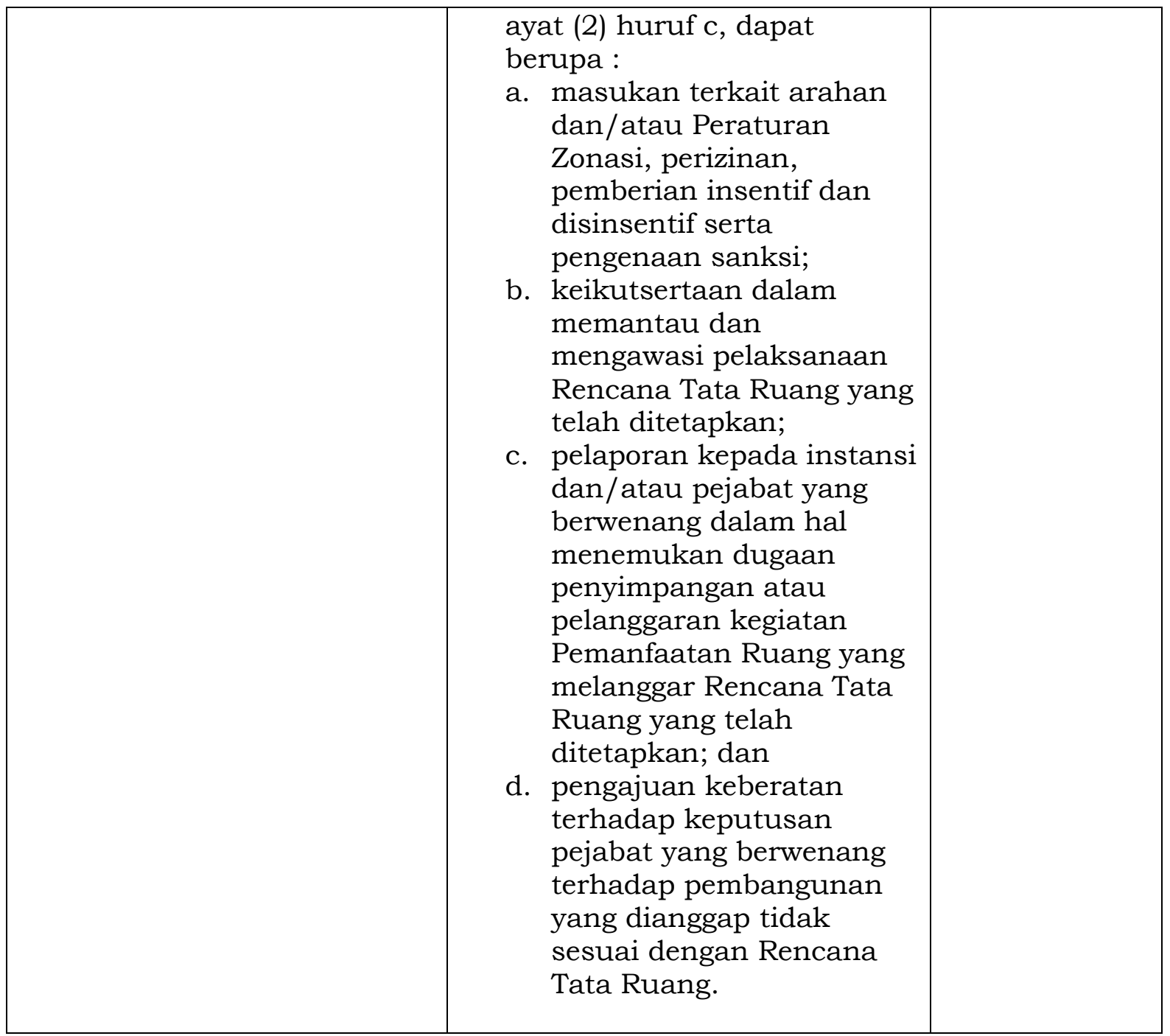

Diolah dari Peraturan Daerah Kabupaten Badung Nomor 15 Tahun 2013 Tentang Perlindungan Perempuan Dan Anak Korban Kekerasan dan Peraturan Daerah Kabupaten Badung Nomor 26 Tahun 2013 Tentang Rencana Tata Ruang Wilayah Kabupaten Badung Tahun 2013 - 2033.

Dengan demikian maka urgensi partisipasi publik dalam pembentukan kebijakan daerah adalah dapat dilihat dari manfaatnya yaitu dalam meningkatkan kualitas keputusan yang dibuat karena didasarkan pada kepentingan dan pengetahuan riil yang ada dalam masyarakat. Partisipasi publik juga sangat bermanfaat dalam membangun komitmen masyarakat untuk membantu penerapan suatu keputusan yang telah dibuat. Komitmen ini merupakan modal yang utama bagi keberhasilan sebuah implementasi suatu kebijakan daerah yang berujung pada upaya mewujudkan good governance.

Anak Agung Istri Ari Atu Dewi; Luh Nila Winarni, Penjabaran Prinsip Demokrasi Dalam Pembentukan Kebijakan Daerah 


\section{PENUTUP}

\section{Simpulan}

Berdasarkan rumusan masalah yang diajukan maka dapat ditarik simpulan sebagai berikut :

1. Pinsip Demokrasi merupakan pencerminan asas keterbukaan. Dalam proses pembentukan kebijakan daerah, partisipasi public merupakan pentahapan yang wajib ada Dalam pembentukan peraturan daerah asas keterbukaan sebagai salah satu asas formal sesuai Pasal 5 Undang-Undang Nomor 12 tahun 2011 tentang Pembentukan Peraturan Perundang-undangan penting untuk dikaji dengan menyesuaikan dengan cita hukum dan hidup bersama. mengandung arti membuka diri terhadap hak masyarakat untuk memperoleh informasi yang benar, jujur dan tidak diskriminatif baik mulai dari perencanaan, persiapan, penyusunan dan tahap pembahasan serta seluruh lapisan masyarakat mempunyai kesempatan yang seluas-luasnya untuk memberikan masukan dalam proses pembentukan peraturan daerah. Demikian pula dalam pembentukan Peraturan Daerah Kabupaten Badung Nomor 15 Tahun 2013 tentang Perlindungan Perempuan dan Anak Korban Kekerasan dan Peraturan Daerah Kabupaten Badung Nomor 26 Tahun 2013 Tentang Rencana Tata Ruang Wilayah Kabupaten Badung Tahun 2013 - 2033 juga melalui pentahapan konsultasi publik, dimana melibatkan partisipasi masyarakat dalam proses pembentukan perda dimaksud yang merupakan cerminan dari asas keterbukaan. Demikian pula ketika merefleksikan nilai nilai demokrasi dalam norma pasal tetap perpedoman pada aturan hukum nomatif yaitu mendasarkan pada konstitusi, undang-undang dan aturan hukum lainya. Oleh karena itu dapat dipahami bersama bahwa makna prinsip demokrasi dalam pembentukan kebijakan daerah dalam konteks ini adalah Perda yaitu asas keterbukaan yang partisipatif.

2. Penjabaran prinsip demokrasi berarti implementasi prinsip demokrasi dalam proses pembentukan kebijakan daerah. Ketika menjabarkan prinsip demokrasi dalam proses pembentukan Perda dapat dilihat dalam partisipasi public yang berbentuk konsultasi publik secara langsung maupun tidak langsung. Dalam Partisipasi langsung, bahwa masyarakat terlibat langsung dalam proses pembentukan Kebiajakan daerah. Dalam arena ini masyarakat dapat memberikan masukan dan penyaluran aspirasi kepada pemerintah terkait dengan pokok-pokok pemikiran yang merupakan materi muatan perda, dalam hal ini ditekannkan pada perda Perda Nomor 15 Tahun 2013 Tentang Perlindungan Perempuan Dan Anak Korban Kekerasan dan Peraturan Daerah Kabupaten Badung Nomor 26 Tahun 2013 Tentang Rencana Tata Ruang Wilayah Kabupaten Badung Tahun 2013 - 2033. Lebih lanjut keterlibatan dan keterserapan aspirasi masyarakat telah diatur secara normative dalam Perda

Anak Agung Istri Ari Atu Dewi; Luh Nila Winarni, Penjabaran Prinsip Demokrasi Dalam Pembentukan Kebijakan Daerah 
dimaksud. Sebagaiaman diketahui bahwa dalam Perda Nomor 15 Tahun 2013, sehinga penjabaran prinsip demokrasi dalam Perda Nomor 15 Tahun 2013 Tentang Perlindungan Perempuan Dan Anak Korban Kekerasan diatur dalam Bab XI pasal 16 tentang Partisipasi Masyarakat. Sedangkan dalam Peraturan Daerah Kabupaten Badung Nomor 26 Tahun 2013 Tentang Rencana Tata Ruang Wilayah Kabupaten Badung Tahun 2013 - 2033 telah pula diatur dalam Bab XII tentang Hak, Kewajiban Dan Peran Masyarakat khususnya dalam Bagian Ketiga Pasal 109. Dengan diaturnya secara normative tentang partisipasi masyarakat akan lebih melegalkan komitmen pemerintah dengan masyarakat terkait dengan penerapan kebijakan daerah (Perda) untuk mewujudkan good governance.

\section{Saran}

1. Dalam tahap pembentukan peraturan daerah, partisipasi masyarakat masih bersifat parsial dan simbolik, oleh sebab itu perlu dilibatkan masarakat secara profesional.

2. Pemerintah perlu memebuat strategi untuk lebiih aktif melibatkan masyarakat dalam pembentukan peraturan daeran sehingga menghasilkan perda yang partisipatif.

\section{DAFTAR PUSTAKA}

Abdulkadir Muhammad, 2004, Hukum dan Penelitian Hukum, Bandung, PT. Citra Aditya Bakti.

Ann Seidman, Robert B Seidman dan Nelis Abeyeskere, 2002, Penyususnan Rancangan Undang-Undang Dalam Perubahan Masyarakat Yang Demokratis, Sebuah Panduan Untuk Pembuat Rancangan UndangUndang, yang diterjemahkan oleh Dr. Johanes Usfunan, Endah P Wardhani, Ningrum Sirait, Business Advisory Indonesia, University of San Francisco School of Law Indonesia Program, ELIPS II.

Abdul Aziz Hakim, 2011, Negara Hukum dan Demokrasi Di Indonesia, Yogyakarta: Pustaka Pelajar.

Agus Santoso H.M., 2012, Hukum, Moral \&Keadilan Sebuah Kajian Filsafat Hukum, Jakarta: Prenada Media Group.

Anak Agung Istri Ari Atu Dewi; Luh Nila Winarni, Penjabaran Prinsip Demokrasi Dalam Pembentukan Kebijakan Daerah 
Bernard Arif Sidharta, 2009, "Penelitian Hukum Normatif : Analisis Penelitian Filosofikal dan Dogmatikal", dalam Metode Penelitian Hukum Konstelasi dan Refleksi, , Jakarta: Yayasan Obor Indonesia.

Fikri, M. S., \& Adytyas, N. O. (2018). Politik Identitas dan dan penguatan Demokrasi Lokal (Kekuatan Wong kito dalam demokrasi lokal).

Hans Kelsen, General Theory of Law \& State, with a new introduction by A Javier Trevino, Trancaction Publiher New Brunswick (U.S.A.) and London (U.K.0).

1992, Introduction To The Problems of Legal Theory, translation of the First Edition of the Reine Rechtslehre or Pure Theory of law, Oxford University Press, Walton Street, Oxford ox2 6 dp, Oxford New York Toronto.

Clark New jersey.

Hadjon, Philipus M 1999, "Keterbukaan Pemerintahan Dalam Mewujudkan pemerintahan Yang Demokratis (suatu Pemikiran dalam usaha meningkatkan perwujudan asas demokrasi dalam penyelenggaraan pemerintahan di Indonesia)", Pidato dalam rangka Lustrum III Ubhara Surya di Surabaya.

Irfan Islamy, M, 1997, Prinsip-Prinsip Perumusan Kebijaksanaan Negara, Jakarta: Bumi Aksara.

Joko Widodo, 2001, Good Governance Telaah dari Dimensi Akuntabilitas dan Kontrol Birokrasi Pada Era Desentralisasi dan Otonomi Daerah, Surabaya: Penerbit Insan Cendikia.

Jazim Hamidi, 2006, Revolusi Hukum Indonesia: Makna, Kedudukan dan Implikasi Hukum Naskah Proklamasi 17 Agustus 1945 dalam Sistem Ketatanegaraan RI, Konstitusi Press, Jakarta dan Yogyakarta, Citra Media,.

, 2008, Panduan Praktis Pembentukan Peraturan Daerah Partisipatif, Prestasi Pustaka Publisher.

Janedjri M. Gaffar, 2013, Demokrasi dan Pemilu Di Indonesia, Jakarta: Konstitusi Press khasanah peradaban hukum \& konstitusi.

Lambajang, A. A., Saerang, D. P., \& Morasa, J. (2018). Pengaruh Pengetahuan Tentang Anggaran, Partisipasi Masyarakat, Transparansi Kebijakan

Anak Agung Istri Ari Atu Dewi; Luh Nila Winarni, Penjabaran Prinsip Demokrasi Dalam Pembentukan Kebijakan Daerah 
Publik, Dan Akuntabilitas Publik Terhadap Pengawasan Keuangan Daerah Pada Dewan Perwakilan Rakyat Daerah di Wilayah Sulawesi Utara. Jurnal Riset Akuntansi Dan Auditing" Goodwill", 9(1).

Mahfud MD, Moh.,2009, Politik Hukum Di Indonesia, Jakarta: Rajawali Pers.

Mukthie Fadjar, A, 2004, Tipe Negara Hukum, Malang: Bayumedia Publishing.

------------------, 2014, Teori-Teori Hukum Kontenporer, Malang: Setara Press (Kelompok Penerbit Intrans).

Parsa, I Wayan 2009, "Sanksi Paksaan Pemerintah (Bertuursdwang) Dalam Rangka Penegakan Peraturan Daerah", Pidato Pengukuhan Jabatan Guru BEsar Tetap Bidang Ilmu Hukum/Hukum administrasi Negara pada Fakultas Hukum Universitas Udayana, Sabtu, 21 November 2009.

Peter Mahmud Marzuki, 2005, Penelitian Hukum, Jakarta: Prenada Media

Peraturan Menteri Dalam Negeri Nomor 1 Tahun 2014 tentang Pembentukan Produk Hukum Daerah.

Peraturan Daerah Kabupaten Badung Nomor 15 Tahun 2013 Tentang Perlindungan Perempuan dan Anak Korban Kekerasan.

Peraturan Daerah Kabupaten Badung Nomor 26 Tahun 2013 Tentang Rencana Tata Ruang Wilayah Kabupaten Badung Tahun 2013 - 2033

Rahman, M. (2018). Demokrasi Dalam Filsafat Pendidikan Barat Dan Islam (Kajian Tentang Nilai-Nilai Demokrasi Dan Implementasinya Dalam Konteks Pendidikan Indonesia). Jurnal Cendekia, 3(2).

Sirajuddin, didik Sukrino, Winardi, 2011, Hukum Pelayanan Publik Berbasis Partisipasi dan Keterbukaan Informasi, Malang: Setara Press.

Soetandyo Wignjosoebroto, 2009, “Ragam-Ragam Penelitian Hukum” dalam Metode Penelitian Hukum Konstelasi dan Refleksi, Jakarta: Yayasan Obor Indonesia.

Soerjono Soekanto dan Sri Mamuji, 2004, Penelitian Hukum Normatif Suatu Tinjauan Singkat, Jakarta: PT Raja Grafindo Persada.

Undang-Undang Nomor 12 Tahun 2011 tentang Pembentukan Peraturan Perundang-Undangan.

Undang-Undang Nomor 23 TAhun 2014 tentang Pemerintahan Daerah.

Anak Agung Istri Ari Atu Dewi; Luh Nila Winarni, Penjabaran Prinsip Demokrasi Dalam Pembentukan Kebijakan Daerah 
Wairocana, I Gusti Ngurah 2008, "Implementasi Good Governance Dalam Legislasi Daerah" Pidato Pengukuhan jabatan Guru Besar Tetap dalam Bidang Ilmu Hukum Administrasi PAda Fakultas Hukum Universitas Udayana, Tanggal 22 November 2008.

Zainuddin Ali, H 2009, Metode Penelitian Hukum, Jakarta; Sinar Grafika.

Zaini, Z. D. (2019). Perspektif Hukum Sebagai Landasan Pembangunan Ekonomi Di Indonesia (Sebuah Pendekatan Filsafat). Jurnal Hukum, 28(2), hlm. 929-957.

Anak Agung Istri Ari Atu Dewi; Luh Nila Winarni, Penjabaran Prinsip Demokrasi Dalam Pembentukan Kebijakan Daerah 